\title{
MENINGKATKAN HASIL BELAJAR SISWA DALAM PEMBELAJARAN PKn MENGGUNAKAN MODEL PEMBELAJARAN MAKE A MATCH DI KELAS IX DI SMP NEGERI 7 SALATIGA
}

\author{
Oleh : \\ Nani Mediatati \\ Universitas Kristen Satya Wacana Salatiga \\ e-mail: nani.mediatati@staff.uksw.edu \\ Ferditya Ardhiyanto \\ Universitas Kristen Satya Wacana Salatiga
}

\begin{abstract}
ABSTRAK
Penelitian tindakan kelas ini bertujuan untuk meningkatkan hasil belajar siswa dalam pembelajaran PKn menggunakan model pembelajaran Make A Match di kelas IX D SMP Negeri 7 Salatiga. Hasil belajar siswa yang rendah disebabkan masih digunakannya metode ceramah dibantu media buku cetak ketika guru mengajar, sehingga siswa pasif dan kurang memahami materi. Penggunaan model pembelajaran Make A Match merupakan bentuk tindakan perbaikan pembelajaran yang dipilih untuk meningkatkan hasil belajar siswa. Prosedur penelitian meliputi tahap perencanaan, pelaksanaan tindakan dan pengamatan, serta refleksi yang dilakukan dalam dua siklus. Teknik pengumpulan data melalui observasi dan tes, sedangkan analisis data menggunakan teknik deskriptif komparatif. Hasil penelitian menunjukkan adanya peningkatan hasil belajar siswa. Sebelum tindakan hanya 6 siswa $(23,08 \%)$ yang tuntas $K K M \geq 75$. Setelah tindakan pada siklus I meningkat menjadi 20 siswa $(76,92 \%)$ tuntas KKM dan pada siklus II menjadi 26 siswa (100\%) tuntas KKM. Hasil penelitian ini dapat disimpulkan bahwa penggunaan model pembelajaran Make A Match dalam pembelajaran PKn dapat meningkatkan hasil belajar siswa.
\end{abstract}

Kata kunci : Model Pembelajaran Make A Match, Hasil Belajar 


\section{PENDAHULUAN}

Tujuan pendidikan adalah untuk mengembangkan potensi peserta didik agar menjadi manusia yang beriman dan bertaqwa kepada Tuhan Yang Maha Esa, berakhlak mulia, sehat, berilmu, cakap, kreatif, mandiri dan menjadi warga negara yang demokratis serta bertanggungjawab (Trianto, 2009: 1). Dalam mencapai tujuan pendidikan tersebut yang mempunyai tanggung jawab dan bersentuhan langsung dengan proses pelaksanaannya adalah guru, sebagaimana dikemukakan oleh Kartono (1995: 6) bahwa guru adalah garda terdepan dalam mencerdaskan kehidupan suatu bangsa, oleh karena itu guru dituntut untuk menguasai bahan pelajaran yang akan diajarkan, dan memiliki tingkah laku yang tepat dalam mengajar. Demikian juga menurut M. Firdaus Zarkasi (dalam Asmani, 2011: 25) yang menyatakan bahwa dalam proses belajar mengajar guru harus mampu menguasai berbagai metode, agar siswa dapat belajar secara efektif dan efisien. Berdasarkan kedua pendapat tersebut menunjukkan bahwa agar siswa dapat belajar secara efektif dan efisien sehingga dapat mencapai hasil belajar yang baik ditentukan oleh bagaimana guru mengajar, menguasai materi ajar dan berbagai metode mengajar.

Pendidikan Kewarganegaraan (PKn) merupakan mata pelajaran yang bertujuan untuk meng-
Indonesia-kan para siswa secara sadar, cerdas, dan penuh tanggung jawab (Aziz Wahab dalam Cholisin, 2000: 17). Dengan kata lain PKn bertujuan untuk membentuk siswa menjadi warga negara Indonesia yang cerdas serta bersikap dan berperilaku yang baik dan bertanggunGjawab. Tujuan Pendidikan Kewarganegaraan akan dapat tercapai apabila guru PKn mampu atau mempunyai keterampilan menerapkan berbagai metode/model pembelajaran, diantaranya adalah model pembelajaran kooperatif. Roger, dkk (dalam Huda, 2011:29) menyatakan bahwa pembelajaran kooperatif merupakan aktivitas pembelajaran kelompok yang diorganisir oleh suatu prinsip bahwa pembelajaran harus didasarkan pada perubahan informasi secara sosial diantara kelompok-kelompok pembelajaran yang di dalamnya setiap pembelajaran bertanggung jawab atas pembelajarannya sendiri dan didorong untuk meningkatkan pembelajaran anggota-anggota yang lain. Penelitian dan review yang dilakukan oleh Johnson, dkk (dalam Huda, 2011:17) menunjukkan bahwa pembelajaran kooperatif (cooperative learning) merupakan metode pengajaran efektif dalam meningkatkan prestasi dan sosialisasi siswa sekaligus turut berkontribusi bagi perbaikan sikap dan persepsi mereka tentang begitu pentingnya belajar dan bekerja sama, termasuk 
bagi pemahaman mereka tentang teman-temannya yang berasal dari latar belakang etnis yang berbeda. Melalui pembelajaran kooperatif ini tidak hanya hasil belajar siswa pada aspek kognitif yang dapat ditingkatkan tetapi juga terbentuk sikap sosial dari siswa yaitu sikap bekerjasama, saling membantu, menghormati keperbedaan dan lainlain.

Namun demikian dalam kenyataan pembelajaran $\mathrm{PKn}$ di sekolah guru belum terbiasa menerapkan model pembelajaran kooperatif ini, mereka masih menggunakan model pembelajaran konvensional. Berdasarkan hasil pengamatan terhadap pembelajaran PKn pada materi Dinamika Perwujudan Pancasila Sebagai Dasar Negara dan Pandangan Hidup di kelas IX D SMP Negeri 7 Salatiga ditemukan bahwa guru hanya menggunakan metode ceramah dalam menjelaskan materi, siswa pasif hanya mendengarkan dan mencatat penjelasan guru tanpa ada respon siswa yang aktif seperti bertanya kepada guru, mengemukakan pendapat, menjawab pertanyaan yang diberikan guru, dan bahkan ada siswa yang tidak memperhatikan penjelasan guru. Selanjutnya berdasarkan data dokumentasi nilai ulangan harian atau tes materi tersebut menunjukkan bahwa hasil belajar sebagian besar siswa tidak tuntas mencapai KKM $\geq 75$. Siswa yang mendapat nilai tuntas $\mathrm{KKM} \geq 75$ hanya 6 siswa (23.08\%) dan sebanyak 20 siswa $(76,92 \%)$ tidak tuntas. Hasil belajar sebagian besar siswa yang masih rendah tersebut dikarenakan guru masih dominan menggunakan metode ceramah, sehingga siswa dalam pembelajaran kurang aktif dan kreatif serta kurang dapat memahami materi secara baik. Guru hanya mengandalkan buku cetak sebagai media penunjang utama pembelajaran, sehingga membuat siswa menjadi cepat bosan dalam mengikuti proses pembelajaran. Disamping itu interaksi antara guru dan siswa, juga antara siswa dengan siswa sangat kurang sehingga membuat keadaan kelas menjadi kurang komunikatif. Jika kelas kurang komunikatif jelas membuat suasana belajar kurang nyaman. Hal ini terlihat dari kurangnya guru memberikan kesempatan kepada siswa untuk saling bertukar pikiran guna memahami materi yang sedang dibahas.

Berdasarkan permasalahan tersebut maka perlu dilakukan perbaikan pembelajaran melalui penelitian tindakan kelas untuk meningkatkan hasil belajar siswa dalam mata pelajaran PKn di kelas IX D melalui penerapan model pembelajaran kooperatif. Robert Slavin dan rekan-rekannya mengenalkan pembelajaran kooperatif di lingkungan pendidikan melalui metode metodenya yang terkenal, seperti Jigsaw, Team- 
Game-Tournament (TGT), Student Teams Achievement Divisions (STAD), Learning Together, Think Pair Share (TPS), Make A Match dan sebagainya (Tukiran, 2012:56). Dalam penelitian ini dipilih metode/model pembelajaran Make A Match. Model pembelajaran Make A Match adalah sistem pembelajaran yang mengutamakan penanaman kemampuan sosial terutama kemampuan bekerja sama, kemampuan berinteraksi di samping kemampuan berpikir cepat melalui permainan mencari pasangan dengan dibantu kartu (Wahab, 2007: 59). Suyatno (2009: 72) mengungkapkan bahwa Make A Match adalah model pembelajaran dimana guru menyiapkan kartu yang berisi soal atau permasalahan dan menyiapkan kartu jawaban kemudian siswa mencari pasangan kartunya. Anita Lie (2008: 56) menyatakan bahwa model pembelajaran Make A Match atau bertukar pasangan merupakan teknik belajar yang memberi kesempatan siswa untuk bekerjasama dengan siswa lain. Teknik ini bisa digunakan dalam semua mata pelajaran dan untuk semua tingkatan usia anak didik. Model ini diyakini bisa meningkatkan hasil belajar siswa karena di dalam pelaksanaan model pembelajaran Make A Match guru tidak lagi mendominasi kegiatan pembelajaran dengan metode ceramah karena siswa dituntut lebih aktif mengikuti kegiatan pembelajaran. Dengan model pembelajaran Make A Match penyampaian materi akan diberikan kepada siswa dalam bentuk yang lebih menarik yakni dalam bentuk kartu yang memuat jawaban dan soal sebelum dibagikan kepada siswa. Kartu yang memuat jawaban dan soal tersebut akan dikocok terlebih dahulu sehingga akan lebih menarik ketika dibagikan karena siswa akan menerimanya dalam bentuk acak dan harus mencari siapa pasangannya. Kemudian siswa diberi kesempatan untuk mencari pasangan dari kartu tersebut, bagi siswa yang telah menemukan pasangannya sebelum batas waktu yang ditentukan akan mendapatkan poin dan bagi siswa yang melampui batas waktu akan mendapatkan hukuman. Namun hukuman yang diberikan hanya bersifat memotivasi siswa supaya lebih giat dan bersungguh-sungguh dalam mencari pasangan kartu. Bentuk hukuman yang akan diberikan disesuaikan dengan kesepakatan bersama oleh siswa di kelas. Kemudian setelah selesai kartu dikocok dan dibagikan kembali kepada siswa dengan begitu setiap siswa akan menerima soal dan jawaban dalam bentuk berbeda. Menurut Lona Curren dalam Anita Lie (2008:55) keunggulan model pembelajaran Make A Match antara lain: (1) dapat meningkatkan aktivitas belajar siswa, baik secara kognitif maupun fisik; (2) karena ada unsur permainan, model ini menyenangkan; (3) meningkatkan 
pemahaman siswa terhadap materi yang dipelajari dan dapat meningkatkan motivasi belajar siswa; (4) efektif sebagai sarana melatih keberanian siswa untuk tampil presentasi; dan (5) efektif melatih kedisiplinan siswa menghargai waktu untuk belajar.

Melalui penerapan model pembelajaran Make A Match siswa dapat belajar mengenai suatu konsep dalam suasana menyenangkan dan akhirnya bisa memotivasi siswa untuk memahami materi yang disampaikan dan hasil belajar siswa dapat meningkat. Hasil penelitian Hudi (2014), tentang Upaya Peningkatan Hasil Belajar IPS Ekonomi dengan menggunakan model pembelajaran Make A Match bagi siswa kelas VIIH SMP Negeri 6 Salatiga Semester Gasal Tahun Ajaran 2013/2014 menunjukkan bahwa dalam menyampaikan materi Ilmu Pengetahuan Sosial (IPS) pada kompetensi dasar Kebutuhan Manusia dan Kelangkaan Sumberdaya dengan menggunakan model pembelajaran Make A Match, ternyata siswa lebih antusias dalam mengikuti pembelajaran dan memotivasi siswa untuk lebih memahami konsep/materi. Jika sebelum menggunakan model pembelajaran Make A Match hasil belajar mencapai nilai rata-rata 6,25. Setelah menggunakan model pembelajaran Make A Match hasil belajar pada siklus I mencapai nilai rata-rata 7,2 dan siklus II mencapai nilai rata-rata 8,97,2. Selanjutnya hasil penelitian Ayu Rahmaningtias (2011) tentang Penerapan Model Pembelajaran Kooperatif Make A Match Untuk Meningkatkan Hasil Belajar IPS Siswa Kelas VIII-A SMP Negeri 2 Diwek Jombang menunjukkan ada peningkatan hasi 1 belajar IPS siswa setelah diterapkan Model Pembelajaran Kooperatif Make A Match. Ratarata nilai sebelum tindakan adalah 66,9 mengalami peningkatan pada Siklu s 1 menjadi 73,2 dan meningkat lagi pada Siklus 2 menjadi 83,7. Ketuntasan belajar $\mathrm{k}$ lasikal sebelum tindakan adalah sebesar $41,0 \%$, meningkat pada Siklus 1 menjadi $61,5 \%$, dan meningkat

lagi pada Siklus 2 menjadi 89,7 $\%$. Sehingga dapat disimpulkan bahwa pembelajaran dengan menggunakan model Make A Match dapat meningkatkan hasil belajar siswa.

Berdasarkan kajian teori dan hasil penelitian tersebut di atas maka dilakukan penelitian tindakan kelas untuk meningkatkan hasil belajar siswa dalam mata pelajaran PKn materi Kepatuhan Terhadap Hukum dengan menggunakan model pembelajaran Make A Match di Kelas IXD SMP Negeri 7 Salatiga Semester 1 Tahun ajaran 2016/2017. 


\section{METODE PENELITIAN}

Jenis penelitian adalah Penelitian Tindakan Kelas dengan model spiral/siklus yang terdiri dari empat tahapan yaitu perencanaan (planing), pelaksanaan tindakan (action), observasi (observation), dan refleksi (reflection) ( Kemmis dan Mc Taggart dalam Arikunto Suharsimi, 2002: 97). Penelitian dilaksanakan di SMP Negeri 7 Salatiga dari bulan Oktober sampai dengan Desember 2016 dalam 2 siklus dan setiap siklus terdiri dari 2 kali pertemuan. Subyek penelitian adalah siswa kelas IXD yang berjumlah 26 siswa terdiri dari 10 siswa laki-laki dan 16 siswa perempuan. Teknik pengumpulan data menggunakan dokumentasi, observasi dan tes yang telah diuji validitas dan reliabilitasnya. Data yang terkumpul dianalisis dengan teknik deskriptif komparatif dengan membandingkan prosentase ketuntasan hasil belajar siswa sebelum tindakan dan setelah tindakan pada siklus I dan siklus II. Penelitian dikatakan berhasil apabila seluruh siswa kelas IX D (100\%) nilai hasil belajar PPKnnya tuntas mencapai $\mathrm{KKM} \geq 75$. 


\section{HASIL PENELITIAN DAN \\ PEMBAHASAN}

\section{Hasil Belajar Siswa Sebelum Pelaksanaan Tindakan}

Berdasarkan dokumen rekap hasil tes/ulangan dari siswa kelas IXD yang diberikan oleh guru mata pelajaran PKn menunjukkan adanya permasalahan hasil belajar PKn siswa yang rendah. Sebagian besar siswa nilai tesnya belum mencapai $K K M \geq 75$ dan nilai rata-rata kelas juga masih di bawah KKM, hal ini dapat dilihat dalam tabel 1 berikut ini

Tabel 1

Rekapitulasi Nilai PKn Siswa Kelas IX D Sebelum Tindakan

\begin{tabular}{|l|c|c|c|c|}
\hline \multirow{2}{*}{ No } & \multirow{2}{*}{ Nilai } & $\begin{array}{c}\text { Sebelum Tindakan } \\
\text { Jumlah } \\
\text { Siswa }\end{array}$ & $(\%)$ & Keterangan \\
\hline 1 & $<65$ & 12 & 46,15 & Tidak Tuntas \\
\hline 2 & $65-69$ & 5 & 19,23 & Tidak Tuntas \\
\hline 3 & $70-74$ & 3 & 11,54 & Tidak Tuntas \\
\hline 4 & $75-79$ & 4 & 15,39 & Tuntas \\
\hline 5 & $80-84$ & 2 & 7,69 & Tuntas \\
\hline \multicolumn{3}{|c|}{ Jumlah } & 26 & 100,00 \\
\hline \multicolumn{4}{|c|}{ Nilai Rata - Rata } & \multicolumn{5}{|c|}{80} \\
\hline \multicolumn{2}{|c|}{ Nilai Tertinggi } & 40 \\
\hline \multicolumn{2}{|c|}{ Nilai Terendah } & \multicolumn{5}{c}{} \\
\hline
\end{tabular}

Sumber : Data Nilai tes PKn Kelas IX D diolah

Berdasarkan tabel 1 rekapitulasi nilai PKn siswa sebelum tindakan (dalam pembelajaran menggunakan model pembelajaran konvensional/ceramah) dapat diketahui bahwa nilai siswa yang tuntas $\mathrm{KKM} \geq 75$ sebesar 23,08\% (6 siswa) dan tidak tuntas sebesar $76,92 \%$ (20 siswa). Nilai rata-rata kelas: 60, nilai tertinggi: 80 dan nilai terendah: 40.

Hasil belajar siswa yang sebagian besar tidak tuntas KKM ini diduga karena guru menggunakan metode ceramah dalam pembelajaran sehingga suasana pembelajaran membosankan dan kurang memotivasi siswa untuk memahami materi pembelajaran dari guru. Oleh karena itu dilakukan perbaikan pembelajaran dengan menerapkan model pembelajaran Make A Match. Model ini akan membuat suasana pembelajaran menyenangkan karena ada unsur permainan dan meningkatkan motivasi siswa untuk memahami materi pembelajaran melalui kerjasama dengan teman.

\section{Hasil Belajar Siswa Setelah Pelaksanaan Tindakan Pada Siklus I}

Pelaksanaan tindakan pada siklus 1 ini dilakukan 2 x pertemuan, dimulai dengan tahap perencanaan yaitu disusun RPP yang sudah diselaraskan dengan sintaks Make A Match, mengemas materi hakekat 
hukum dan unsur-unsurnya, klasifikasi hukum, dan Indonesia sebagai negara hukum, menyiapkan media proyektor LCD untuk menampilkan gambar peta konsep klasifikasi hukum dan video berkaitan dengan ketertiban pengguna jalan yang wajib mematuhi peraturan lalu lintas, menyiapkan kartu soal dan jawaban berdasarkan kelompok, serta menyiapkan lembar observasi guru dan siswa yang akan diisi oleh observer untuk mengetahui aktifitas guru dan siswa dalam proses pembelajaran.

Selanjutnya pada tahap pelaksanaan setelah kegiatan apersesi guru menjelaskan materi secara singkat dengan menayangkan gambar peta konsep tentang hukum dan klasifikasi hukum supaya siswa lebih memahami materi yang disampaikan dan menayangkan video berkaitan dengan kewajiban pengguna jalan raya untuk mematuhi peraturan lalu lintas supaya siswa memahami tentang pentingnya kepatuhan hukum. Dalam proses ini guru juga memberi kesempatan kepada siswa untuk bertanya apabila belum jelas. Setelah siswa menyatakan sudah jelas terhadap materi yang disampaikan, selanjutnya guru membagi siswa dalam 2 kelompok besar, setiap siswa dalam kelompok 1 diberi kartu soal dan setiap siswa dalam kelompok 2 diberi kartu jawaban. Masing-masing siswa diminta untuk membaca dalam hati soal dan jawaban dalam kartu yang dipegangnya dan memikirkan apa jawaban dari soal yang dibacanya dan apa soal dari jawaban yang dibacanya selama 5 menit dan siswa boleh membaca uraian materi dalam buku paket PKn Kelas XI khususnya Bab III tentang kepatuhan terhadap hukum untuk mencari jawaban dan soal tersebut. Kemudian siswa dalam dua kelompok tersebut diminta untuk mencari pasangan kartu soal dan jawaban dalam waktu 10 menit. Siswa yang berhasil mencocokkan kartunya sebelum batas waktu 10 menit diberi poin oleh guru sedangkan yang belum berhasil menemukan dan mencocokan kartunya melebihi batas waktu diberi sanksi yaitu menyanyikan lagu nasional secara berpasangan. Semua siswa secara berpasangan kemudian menjelaskan kartu soal dan jawaban di depan kelas dan dilakukan diskusi kelas untuk memperjelas pemahaman siswa. Selanjutnya siswa bersama dengan guru menyimpulkan materi. Di akhir pertemuan dilakukan evaluasi/tes untuk mengetahui hasil belajar atau pemahaman siswa terhadap materi pelajaran. Berdasarkan hasil tes diketahui bahwa dari 26 siswa kelas IX D yang mendapat nilai tuntas $\mathrm{KKM} \geq 75$ sebanyak 20 siswa $(76,92 \%)$ dan sisanya 6 siswa $(23,08 \%)$ belum tuntas $\mathrm{KKM} \geq 75$.

Rekapitulasi perolehan hasil belajar PKn siswa kelas IX D siklus I dapat dilihat pada tabel 2 berikut. 
Tabel 2

Rekapitulasi Hasil Belajar PKn Siswa Kelas IX D Pada Siklus I

\begin{tabular}{|c|c|c|c|c|}
\hline \multirow[t]{2}{*}{ No } & \multirow[t]{2}{*}{ Nilai } & \multicolumn{2}{|c|}{ Siklus I } & \multirow[t]{2}{*}{ Keterangan } \\
\hline & & Jumlah Siswa & $(\%)$ & \\
\hline 1 & $<65$ & 3 & 11,54 & Tidak Tuntas \\
\hline 2 & $65-69$ & 2 & 7,69 & Tidak Tuntas \\
\hline 3 & $65-74$ & 2 & 3,85 & Tidak Tuntas \\
\hline 4 & $75-79$ & 8 & 30,77 & Tuntas \\
\hline 5 & $80-84$ & 6 & 23,08 & Tuntas \\
\hline 6 & $85-89$ & 2 & 7,69 & Tuntas \\
\hline 7 & $90-94$ & 4 & 15,38 & Tuntas \\
\hline \multicolumn{2}{|c|}{ Jumlah } & 26 & \multicolumn{2}{|c|}{100,00} \\
\hline \multicolumn{2}{|c|}{ Nilai rata - rata } & \multicolumn{3}{|l|}{80,62} \\
\hline \multicolumn{2}{|c|}{ Nilai tertinggi } & \multicolumn{3}{|l|}{92} \\
\hline \multicolumn{2}{|c|}{ Nilai terendah } & \multicolumn{3}{|l|}{50} \\
\hline
\end{tabular}

Berdasarkan tabel 2 dapat diketahui bahwa dari 26 siswa kelas IX D yang mendapat nilai < 65 berjumlah 3 siswa atau 11,54\%, siswa yang mendapat nilai pada rentang $65-69$ berjumlah 2 siswa atau $7,69 \%$, siswa yang mendapat nilai pada rentang $70-74$ adalah 1 siswa atau $3,85 \%$. Dengan demikian masih ada 6 siswa yang belum tuntas $K K M \geq 75$. Kemudian siswa yang mendapat nilai pada rentang $75-79$ berjumlah 8 siswa atau $30,77 \%$, siswa yang mendapat nilai $80-84$ berjumlah 6 siswa atau 23, 08\%, siswa yang mendapat nilai $85-89$ berjumlah 2 siswa atau $7,69 \%$. Siswa yang mendapat nilai $90-94$ berjumlah 4 siswa atau 15,38\%, sehingga dapat diketahui siswa yang mendapat nilai tuntas melebihi KKM $\geq 75$ ada 20 siswa. Nilai rata - rata adalah 80,62, nilai tertinggi adalah 92 dan nilai terendah adalah 50 . Karena hasil belajar belum menunjukkan indikator keberhasilan sebesar $100 \%$ tuntas KKM, maka perlu dilanjutkan pelaksanaan siklus II. Berdasarkan observasi terhadap pelaksanaan pembelajaran siswa lebih memperhatikan penjelasan guru karena digunakan power point peta konsep dan video. Siswa aktif mencari pasangan kartu soal dan jawaban serta menjelaskan di depan kelas, namun masih ada beberapa siswa yang lambat dan bingung dalam menemukan pasangan kartunya, dan dalam menjelaskan di depan kelas dengan pasangannya masih takut salah. Hasil belajar yang dicapai siswa dan hasil observasi tersebut dijadikan refleksi guru untuk melakukan perbaikan tindakan pada siklus berikutnya. Pada siklus II guru akan lebih memotivasi siswa untuk lebih cepat menemukan pasangannya dan tidak takut memberikan penjelasan di depan kelas dengan memberikan reward berupa alat tulis selain poin. Pemahaman siswa terhadap materi akan ditingkatkan dalam diskusi kelas. 


\section{Hasil Belajar Setelah Pelaksanaan Tindakan Pada Siklus II}

Perencanaan dan pelaksanaan tindakan pada siklus 2 sama dengan siklus 1 tetapi dengan materi yang berbeda yaitu arti pentingnya hukum dalam kehidupan bermasyarakat serta bentuk perilaku yang sesuai dan tidak sesuai dengan hukum. Hasil observasi terhadap pelaksanaan pembelajaran menunjukkan siswa makin fokus terhadap penjelasan guru, aktif bertanya terhadap materi yang belum jelas, berlomba untuk cepat menemukan kartu pasangannya dan lebih percaya diri dalam menjelaskan karena ada dobel reward yaitu dapat poin dan alat tulis, diskusi kelas berlangsung aktif, suasana kelas kondusif dan menyenangkan. Hasil evaluasi/tes yang menunjukkan pemahaman siswa terhadap materi juga makin meningkat.

Hasil belajar PKn siswa kelas IX D pada siklus II dapat dilihat dalam tabel 3 berikut ini.

Tabel 3

Rekapitulasi Hasil Belajar PKn Siswa Kelas IX D Pada Siklus II

\begin{tabular}{|r|c|c|c|c|}
\hline \multirow{2}{*}{ No } & \multirow{2}{*}{ Nilai } & \multicolumn{2}{|c|}{ Siklus II } & \multirow{2}{*}{ Keterangan } \\
\cline { 3 - 5 } & & Jumlah Siswa & $(\%)$ & \\
\hline 1 & $75-79$ & 2 & 7,69 & Tuntas \\
\hline 2 & $80-84$ & 9 & 34,62 & Tuntas \\
\hline 3 & $85-89$ & 7 & 26,92 & Tuntas \\
\hline 4 & $90-94$ & 3 & 11,54 & Tuntas \\
\hline 5 & $95-100$ & 5 & 19,23 & Tuntas \\
\hline \multicolumn{3}{|c|}{ Jumlah } & 26 & \multicolumn{3}{c|}{100,00} \\
\hline Nilai rata - rata & \multicolumn{3}{|c|}{100,84} \\
\hline Nilai tertinggi & \multicolumn{3}{|c|}{78} \\
\hline \multicolumn{2}{|r|}{ Nilai terendah } &
\end{tabular}

Sumber : Daftar Nilai Tes PKn Kelas IX D diolah

Berdasarkan tabel 3 diketahui bahwa dari 26 siswa kelas IX D semua mendapatkan nilai tuntas di atas $\mathrm{KKM} \geq 75$. Hal ini dapat diketahui dari nilai terendah siswa yaitu 78. Nilai rata-rata 92,84 dan nilai tertinggi 100 . Tidak ada lagi nilai siswa yang berada dibawah KKM $\geq 75$. Hasil belajar dari pelaksanaan Siklus II ini sudah mencapai indikator keberhasilan penelitian yaitu $100 \%$ siswa memperoleh nilai tuntas KKM $\geq 75$.

Perbandingan Ketuntasan Hasil Belajar PKn Siswa Sebelum Tindakan (Kondisi Awal), dan Setelah Tindakan Pada Siklus I dan Siklus II.

Peningkatan ketuntasan hasil belajar dari kondisi awal ke siklus I dan siklus II dapat ditunjukkan pada tabel 4 berikut ini. 
Tabel 4

Rekapitulasi Ketuntasan Hasil Belajar PKn Siswa Kelas IX D Pada Kondisi Awal, siklus I, dan Siklus II

\begin{tabular}{|c|c|c|c|c|c|c|c|}
\hline No & Nilai & \multicolumn{2}{|c|}{ Kondisi Awal } & \multicolumn{2}{c|}{ Siklus I } & \multicolumn{2}{c|}{ Siklus II } \\
\cline { 2 - 8 } & $\begin{array}{c}\text { Jumlah } \\
\text { Siswa }\end{array}$ & $(\%)$ & $\begin{array}{c}\text { Jumlah } \\
\text { Siswa }\end{array}$ & $(\%)$ & $\begin{array}{c}\text { Jumlah } \\
\text { Siswa }\end{array}$ & $(\%)$ \\
\hline 1 & Tidak Tuntas & 20 & 76,92 & 6 & 23,08 & 0 & 0 \\
\hline 2 & Tuntas & 6 & 23,08 & 20 & 76,92 & 26 & 100 \\
\hline Jumlah & 26 & 100,00 & 26 & 100,00 & 26 & 100 \\
\hline Nilai rata -rata & \multicolumn{2}{|c|}{60} & \multicolumn{2}{c|}{80,62} & \multicolumn{2}{c|}{92,84} \\
\hline Nilai Tertinggi & \multicolumn{2}{|c|}{80} & \multicolumn{2}{c|}{92} & \multicolumn{2}{c|}{100} \\
\hline Nilai Terendah & \multicolumn{2}{|c|}{40} & \multicolumn{2}{c|}{50} & \multicolumn{2}{c|}{78} \\
\hline
\end{tabular}

Sumber : Daftar Nilai Tes PKn Kondisi Awal, Siklus I dan II diolah

Berdasarkan tabel 4 dapat diketahui bahwa pada kondisi awal hanya 6 siswa atau 23,08\% yang tuntas $\mathrm{KKM} \geq 75$ dan nilai rata-rata kelas 60. Pada siklus I setelah diterapkan model Make A Match meningkat menjadi 20 siswa atau $76,92 \%$ yang tuntas dan nilai ratarata kelas 80,62. Pada siklus II 26 siswa atau $100 \%$ tuntas di atas KKM dan nilai rata-rata kelas 92,84.

\section{PEMBAHASAN}

Berdasarkan penelitian tindakan kelas yang telah dilaksanakan untuk meningkatkan hasil belajar siswa dalam pembelajaran PKn di kelas IX D SMP N 7 Salatiga semester I tahun pelajaran 2016/2017 melalui penerapan model pembelajaran Make A Match dapat ditunjukkan keberhasilan dari penelitian melalui pembahasan di bawah ini.

Kegiatan pelaksanaan siklus I dilaksanakan dalam $2 \mathrm{x}$ pertemuan pada tanggal 1 dan 5 November 2016. Setiap pertemuan dilaksanakan dalam alokasi waktu 80 menit. Pada akhir siklus I atau pertemuan kedua siswa mengerjakan soal tes yang sudah disiapkan sebagai bentuk evaluasi. Persiapan dan pelaksanaan siklus I berdasarkan sintaks pembelajaran Make A Match. Setelah guru menjelaskan materi secara singkat dengan power point peta konsep dan video, pembelajaran lebih ditekankan pada keaktifan siswa dan kerjasama antar siswa. Siswa nampak senang dan aktif dalam pembelajaran, siswa yang memegang kartu soal dan jawaban saling mencari pasangannya, setelah ketemu mendiskusikan dengan pasangannya dan mempresentasikan hasilnya. Siswa saling bertanya dan menjawab serta menanggapi jawaban, dan guru bertindak sebagai fasilitator dan meluruskan jawaban yang kurang tepat. Oleh karena siswa aktif sehingga dapat memahami materi dengan baik. Hal ini dapat dilihat dari hasil evaluasi yang menunjukkan peningkatan ketuntasan hasil belajar siswa. Jumlah siswa yang mendapat nilai tuntas KKM ada 20 siswa atau $76,92 \%$ yang menunjukkan peningkatan dibanding kondisi awal. Kemudian siswa yang mendapat nilai tidak tuntas berjumlah 6 siswa atau 
$23,08 \%$ yang menunjukkan adanya penurunan nilai siswa yang tidak tuntas KKM. Namun demikian peningkatan ketuntasan hasil belajar siswa belum mencapai $100 \%$ sesuai indikator keberhasilan sehingga perlu adanya tindakan perbaikan pembelajaran pada siklus II. Kelemahan yang masih nampak dalam proses pembelajaran yaitu masih ada beberapa siswa yang lambat dan bingung dalam menemukan pasangan kartunya, dan dalam menjelaskan di depan kelas dengan pasangannya masih takut salah.

Selanjutnya siklus II dilaksanakan $2 \mathrm{x}$ pertemuan pada tanggal 8 dan 10 November 2016. Setiap pertemuan dilaksanakan dalam waktu 80 menit. Kegiatan di siklus II tidak jauh berbeda dengan siklus I karena merupakan tindak lanjut dan penyempurnaan dari siklus I. Sehingga tahapan pembelajaran tetap sama dengan siklus I tetapi dengan materi yang berbeda. Kegiatan pembelajaran tetap mengacu pada sintaks Make A Match. Untuk mengatasi kelemahan yang terjadi pada siklus I, guru lebih memotivasi siswa untuk lebih cepat menemukan pasangannya, bekerjasama mendiskusikan soal dan jawaban dengan pasangannya dan tidak takut salah dalam memberikan penjelasan di depan kelas dengan memberikan reward berupa alat tulis selain poin. Disamping itu pemahaman siswa terhadap materi lebih ditingkatkan dalam diskusi kelas.

Suasana pembelajaran sangat menyenangkan walaupun siswa sedikit ramai karena siswa berlomba untuk cepat menemukan pasangannya, bekerjasama mendiskusikan soal dan jawaban dengan pasangannya, dan mempresentasikan di depan kelas. Diskusi kelas berlangsung aktif sehingga siswa benar-benar dapat memahami materi dengan baik, hal ini ditunjukkan oleh peningkatan ketuntasan hasil belajar siswa berdasarkan hasil tes. Seluruh siswa sebanyak 26 siswa, mendapatkan nilai tuntas $\mathrm{KKM}$ sebesar $\geq 75$. Nilai terendah adalah 78 dan tertinggi adalah 100 . Indikator keberhasilan penelitian tercapai yaitu $100 \%$ siswa memperoleh nilai tuntas KKM. Dengan demikian kegiatan pembelajaran PKn yang dilaksanakan dengan menerapkan model pembelajaran Make A Match di kelas IX D pada semester I tahun pelajaran 2016/2017 dapat meningkatkan hasil belajar siswa mulai dari siklus I dan siklus II.

Hasil penelitian ini sesuai dengan kajian teori dan kajian empirik berdasarkan hasil penelitian terdahulu. Menurut Lona Curren dalam Anita Lie (2008: 55) model pembelajaran Make A Match mempunyai keunggulan antara lain: dapat meningkatkan aktivitas belajar siswa, suasana pembelajaran menyenangkan karena ada unsur permainan, dapat meningkatkan pemahaman siswa terhadap materi yang dipelajari dan dapat meningkatkan motivasi belajar siswa. Melalui penerapan model pembelajaran Make A Match siswa dapat belajar mengenai suatu konsep dalam suasana menyenangkan dan bekerjasama dengan teman memahami materi yang disampaikan guru sehingga motivasi belajar dan hasil belajar siswa dapat meningkat. 
Hasil penelitian Hudi (2014) dan Ayu Rahmaningtias (2011) juga menunjukkan bahwa penggunaan model pembelajaran Make A Match dapat meningkatkan hasil belajar IPS Ekonomi dan IPS Geografi siswa kelas VII dan VIII SMP.

\section{SIMPULAN}

Berdasarkan hasil penelitian dan pembahasan dapat disimpulkan bahwa penggunaan model Make $A$ Match dalam pembelajaran PKn dapat meningkatkan hasil belajar siswa kelas IX D SMP Negeri 7 Salatiga semester I tahun pelajaran 2016/2017. Pada siklus I jumlah siswa yang mendapat nilai tuntas KKM $\geq 75$ sebanyak 20 siswa $(76,92 \%)$ dan sisanya 6 siswa $(23,08 \%)$ belum tuntas KKM $\geq$ 75 dan pada siklus II meningkat menjadi 26 siswa (100\%) memperoleh nilai di atas $\mathrm{KKM} \geq$ 75.

\section{DAFTAR PUSTAKA}

Arikunto, Suharsimi. 2002. Metodologi Penelitian. Penerbit PT. Rineka Cipta. Jakarta.

Asmani, Jamal Ma’mur. 2011. 7 Tips Aplikasi Pakem. Jogjakarta: DIVA Press.

Ayu Rahmaningtias. 2011. Penerapan Model Pembelajaran Kooperatif Make A Match Untuk Meningkatkan Hasil Belajar IPS Siswa Kelas VIII-A SMP Negeri 2 Diwek Jombang. Skripsi, Jurusan Pendidikan Geografi FIS Universitas Negeri Malang.

Cholisin. 2000. Materi Pokok Ilmu Kewarganegaraan-Pendidikan Kewarganegaraan. UNY. Yogyakarta

Huda, iftahul. 2011. Cooperative Learning. Yogyakarta: Pustaka Pelajar.

Hudi. 2014. Upaya Peningkatan Hasil Belajar IPS Ekonomi dengan menggunakan model pembelajaran Make A Match bagi siswa kelas VIIH SMP Negeri 6 Salatiga Semester Gasal Tahun Ajaran 2013/2014. Skripsi. Program Studi Pendidikan Ekonomi FKIP UKSW.

Kartono, Kartini. 1995. Psikologi Anak (Psikologi Perkembangan). Bandung: Mandar Maju.

Lie, Anita. 2008. Cooperative Learning: Mempraktikkan Cooperative Learning di Ruang-Ruang Kelas. Jakarta: PT Gramedia Widiasana Indonesia 
Suyatno.2009. Menjelajah Pembelajaran Inofatif. Sidoarjo: Masmedia Buana Pusaka.

Taniredja, Tukiran, dkk. 2011. Model-Model Pembelajaran Inovatif. Bandung: Alfabeta.

Trianto.2009. Mendesain Model Pembelajaran Inovatif - Progresif: Konsep, Landasan, dan Implementasi Pada Kurikulum Tingkat Satuan Pendidikan (KTSP). Jakarta: Kencana Prenada Media Group

Wahab. 2007. Metode dan Model-Model Mengajar. Bandung: Alfabeta. 